\title{
Corrosion Inhibition of Carbon Steel in Acidic Mediaby Using Actinidia deliciosa (Kiwifruit) Extract
}

\author{
M. I. Arias-Montoya1, G. F. Dominguez-Patiño², J. G. Gonzalez-Rodriguez ${ }^{3}$, \\ J. A. Dominguez-Patiño ${ }^{3}$, M. L. Dominguez-Patiño ${ }^{1}$ \\ ${ }^{1}$ Facultad de Ciencias Quimicas e Ingenieria, Universidad Autonoma del Estado de Morelos, \\ Cuernavaca, Mexico \\ ${ }^{2}$ Facultad de Ciencias Biologicas, Universidad Autonoma del Estado de Morelos, Cuernavaca, Mexico \\ ${ }^{3}$ Universidad Autonoma del Estado de Morelos, CIICAP, Cuernavaca, Mexico \\ Email: ggonzalez@uaem.mx
}

Received 9 September 2015; accepted 14 November 2015; published 17 November 2015

Copyright (C) 2015 by authors and Scientific Research Publishing Inc.

This work is licensed under the Creative Commons Attribution International License (CC BY). http://creativecommons.org/licenses/by/4.0/

(c) (i) Open Access

\begin{abstract}
The corrosion inhibition of 1018 carbon steel in $0.5 \mathrm{M} \mathrm{H}_{2} \mathrm{SO}_{4}$ by using Actinidia deliciosa (Kiwifruit) peel extract has been investigated by using potentiodynamic polarization curves and electrochemical impedance spectroscopy. Two kinds of extracts are investigated, one from the tender, and another one from ripe Actinidia deliciosa. Concentrations include 0, 25, 50, 75, and $100 \mathrm{ppm}$ at room temperature. Results indicate that both kind of extracts acted as good corrosion inhibitors, is more efficient in the ripe extract. Corrosion inhibition efficiency increases with increasing its concentration for ripe extract, whereas for the tender Actinidia deliciosa, the higest inhibitor efficiency is obtained by adding $25 \mathrm{ppm}$ and decresaing with a further increase in its concentration. Both extracts improve the passive film properties by decreasing the passive current density values. It is found that the corrosion inhibition is due to the presence of heteroatoms present in Actinidia deliciosa, mainly quercitine, which is physically adsorbed in the steel following a Frumkin type of adsorption isotherm which forms a protective film.
\end{abstract}

\section{Keywords}

Green Inhibitor, Acidic Corrosion, Electrochemical Techniques

\section{Introduction}

The use of corrosion inhibitors is one of the most widely methods to fight corrosion [1]. However, the use of

How to cite this paper: Arias-Montoya, M.I., Dominguez-Patiño, G.F., Gonzalez-Rodriguez, J.G., Dominguez-Patiño, J.A. and Dominguez-Patiño, M.L. (2015) Corrosion Inhibition of Carbon Steel in Acidic Mediaby Using Actinidia deliciosa (Kiwifruit) Extract. Advances in Materials Physics and Chemistry, 5, 447-457. http://dx.doi.org/10.4236/ampc.2015.511045 
synthetic inhibitors has many disadvantages such as damage to the environment, toxic to humans and other living expensive species among others [2]. This is the reazon why in the last years there has been an increasing interest in naturally ocurring inhibitors and has motivated many researchers to focus on the need to develop cheap, non-toxic and environmentally benign natural products such as leaves, fruits or seeds extracts, which can be used as corrosion inhibitors. The reason of this is the presence of complex organic species such as tannins, phenosl, alkaloids, carbohydrates and proteins as well as their acid hydrolysis products [3]-[10]. The use of these natural products is more effective and highly environmentally benign compared to organic and inorganic inhibitors used in chemical or any industrial applications.

Many fruits and vegetables contain high amounts of compounds that have beneficial effects for health, including polyphenols, ascorbic acid, carotenoids and tocopherols. The intake of fruits and vegetables can reduce the risk of chronic diseases such as cardiovascular disease and cancer [11]. Kiwifruit grows naturally in various regions. It has been primarily cultivated in the tropics and subtropics in countries such as New Zealand, Chile, France and Japan. Kiwifruit has been eaten stewed and in jams, jellies, and juices [12]. It contains vitamin C, vitamin A, vitamin E, folic acid, and various phytochemicals. Also, Kiwifruit may reduce the amount of carcinogens [13]. D'Evoli et al. [14] provided original data on the compositional profile and antioxidant capacity of Kiwifruit grown in five orchards of the largest Italian production area (Lazio region). Data on macronutrients (moisture, protein, lipid, carbohydrate), starch, total dietary fiber, oxalic acid, organic acids, minerals, trace elements, and bioactive molecules including ascorbic acid, total polyphenols, carotenoids (lutein and $\beta$-carotene), tocols (a-tocopherol, g-tocopherol, g-tocotrienol) content are reported. Kiwifruit is rich in ascorbic acid. Lutein is the most abundant carotenoid followed by -carotene. Among tocols, -tocopherol is the most abundant followed by g-tocotrienol. Antioxidant activity positively correlates with hydrophilic molecules content mostly with ascorbic acid suggesting vitamin $\mathrm{C}$ as the major contributor to the total antioxidant activity in Kiwifruit. Thus, the goal of this paper is to evaluate the possibility of using Actinidia deliciosa (Kiwifruit) as a green corrosion inhibitor for carbon steel in acidic media such as sulfuric acid.

\section{Experimental Procedure}

Material used in this work was a commercial 1018 carbon steel rods containing $0.14 \%$ C, $0.90 \% \mathrm{Mn}, 0.30 \% \mathrm{~S}$, $0.030 \% \mathrm{P}$ and as balance Fe, encapsulated in commercial resin with an exposed area of $1.0 \mathrm{~cm}^{2}$. The aggressive solution, $0.5 \mathrm{M} \mathrm{H}_{2} \mathrm{SO}_{4}$ was prepared by dilution of analytical grade $\mathrm{H}_{2} \mathrm{SO}_{4}$ with double distilled water. Tender or ripe Actinidia deliciosa (Kiwifruit) were peeled off, soaked in a mixture of 50\% acetone $+50 \%$ hexane during 7 days obtaining by evaporating the solvent. The extract for the ripe Actinidia deliciosa was named Extract 1 , whereas that for the tender one was named Extract 2. The resulting extract was used as a stock solution and characyerized by FTIR technique. Employed electrochemical techniques included potentiodynamic polarization curves and electrochemical impedance spectroscopy measurements, EIS. In all experiments, the carbon steel electrode was allowed to reach a stable open circuit potential value, $E_{\text {corr }}$. Polarization curves were recorded at a constant sweep rate of $1 \mathrm{mV} / \mathrm{s}$ at the interval from -1000 to $+2000 \mathrm{mV}$ respect to the $E_{\text {corr }}$ value. Measurements were obtained by using a conventional three electrodes glass cell with two graphite electrodes symmetrically distributed and a saturated calomel electrode (SCE) as reference with a lugging capillary bridge. Corrosion current density values, $I_{\text {corr }}$, were obtained by using Tafel extrapolation. Inhibition efficiency values $(\eta)$ were determined from the corrosion current densities calculated by the Tafel extrapolation method according to the following equation

$$
\eta(\%)=\left(\frac{I_{\text {corr }}-I_{\text {corr }}^{\prime}}{I_{\text {corr }}}\right) \times 100
$$

where $I_{\text {corr }}^{\prime}$ and $I_{\text {corr }}$ are the corrosion current values with and without inhibitor, respectively. Electrochemical impedance spectroscopy tests were carried out at $E_{\text {corr }}$ by using a signal with amplitude of $10 \mathrm{mV}$ in a frequency interval of $100 \mathrm{mHz}-100 \mathrm{KHz}$. An ACM potentiostat controlled by a desk top computer was used for the polarization curves, whereas for the EIS measurements, a model PC4 300 Gamry potentiostat was used. Selected corroded samples were analyzed in a Scanning Electronic Microscope (SEM).

\section{Results and Discussion}

The effect of Extract 1 of Actinidia deliciosa concentration in the polarization curves for 1018 carbon steel in 
$0.5 \mathrm{M} \mathrm{H}_{2} \mathrm{SO}_{4}$ is shown in Figure 1 where it can be seen that , for the uninhibited solution, polarization curve displays an active-passive behaviour, with the anodic current density increasing as the applied potential increases, up to a potential value where the current density decreases abruptly, reaching a passive current density value, $I_{\text {pas }}$, which remains more or less constant, around $0.5 \mathrm{~mA} / \mathrm{cm}^{2}$, up to a potential value, the pitting potential or $E_{\text {pit }}, 1290 \mathrm{mV}$, where the current density values suddenly increases once again. When $25 \mathrm{ppm}$ of Actinidia deliciosa were added, the corrosion current density value, $I_{\text {corr }}$, slightly decreases, down to a value of 0.13 $\mathrm{mA} / \mathrm{cm}^{2}$, but the $E_{\text {corr }}$ value practically was unafected, as shown in Table 1 . The active-passive behaviour is kept by the steel, and the $I_{\text {pas }}$ value was slightly decreased and so did the $E_{p i t}$ value. As the Actinidia deliciosa concentration increased, the $I_{\text {corr }}$ value decreased reaching its lowest value with the addition of $100 \mathrm{ppm}$. However, tha anodic current density decreased drastically with the addition of either 75 or $100 \mathrm{ppm}$, although the $I_{\text {pas }}$ value decreased also with increasing the Actinidia deliciosa concentration, reaching its lowest value with the addition of $100 \mathrm{ppm}$. Inhibitor efficieny started in a value of 76\% and it increased up to $95 \%$ when $100 \mathrm{ppm}$ of Actinidia deliciosa were added. Anodic and cathodic Tafel slopes remained more or less constant up to an inhibitor concentration of $50 \mathrm{ppm}$, but both of them were drastucally increased with the addition of either 75 or $100 \mathrm{ppm}$, indicating that Actinidia deliciosa is acting as a mixed type of inhibitor, affecting both anodic and cathodic reactions. Thus, it can be seen that one of the effects of Actinidia deliciosa is to omprove the passivaton film properties formed on top of the steel by decreasing the passivation current density. This passive film is formed by the adsorption of a complex formed by $\mathrm{Fe}^{2+}$ ions and the inhibitor [15]-[17].

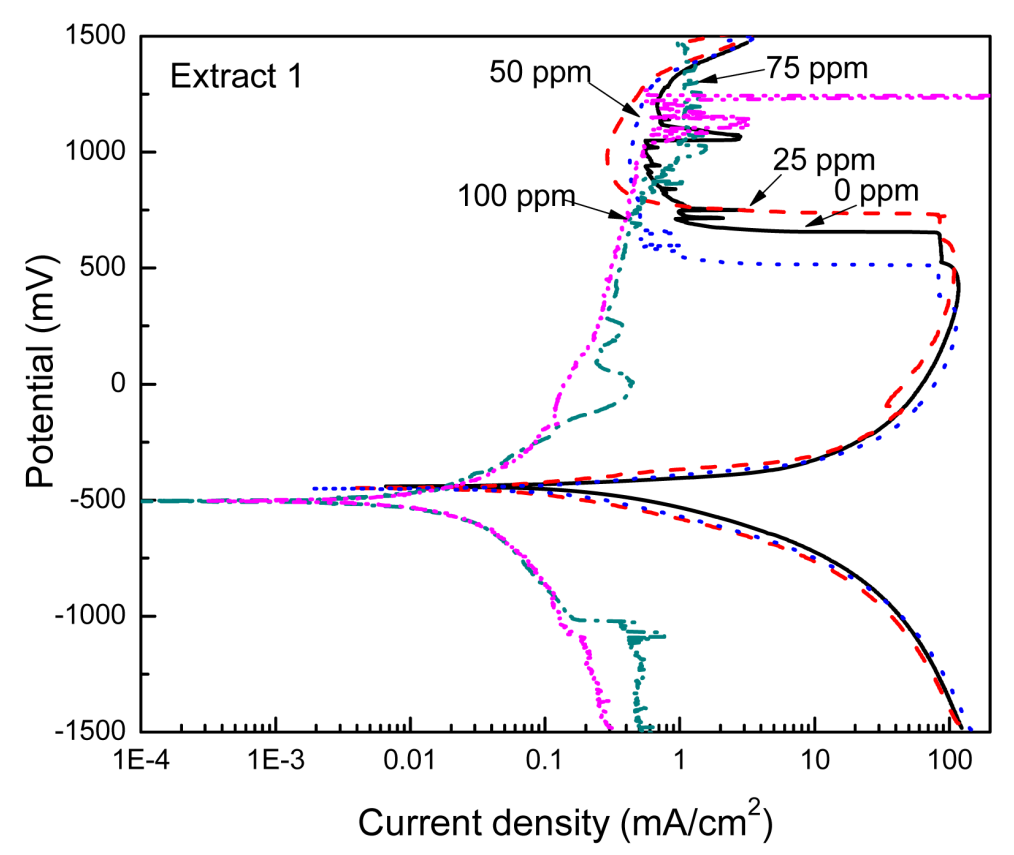

Figure 1. Effect of Extrcat 1 concentration of Actinidia deliciosa on the polazrization curves for 1018 carbon steel in $0.5 \mathrm{M}$ $\mathrm{H}_{2} \mathrm{SO}_{4}$.

Table 1. Electrochemical parameters obtained from polarization curves for 1018 carbon steel in $0.5 \mathrm{M} \mathrm{H}_{2} \mathrm{SO}_{4}$ with additions of Extract 1.

\begin{tabular}{cccccccc}
\hline$C_{\text {inh }}(\mathrm{ppm})$ & $I_{\text {corr }}\left(\mathrm{A} / \mathrm{cm}^{2}\right)$ & $E_{\text {corr }}(\mathrm{mV})$ & $\square(\%)$ & $\square \mathrm{a}(\mathrm{mV} / \mathrm{dc})$ & $\square \mathrm{c}(\mathrm{mV} / \mathrm{dc})$ & $E_{\text {pit }}(\mathrm{mV})$ & $I_{\text {pas }}\left(\mathrm{A} / \mathrm{cm}^{2}\right)$ \\
\hline 0 & 0.54 & -450 & - & 58 & 145 & 1290 & 0.5 \\
25 & 0.15 & -452 & 72 & 52 & 143 & 1275 & 0.3 \\
50 & 0.13 & -448 & 76 & 48 & 154 & 1280 & 0.4 \\
75 & 0.02 & -502 & 95 & 215 & 500 & 960 & 0.4 \\
100 & 0.02 & -504 & 95 & 260 & 500 & 1016 & 0.32 \\
\hline
\end{tabular}


Polarization curves for Extract 2 of Actinidia deliciosa at different concentrations is given in Figure 2, where it can be seen that, regardless of the inhibitor conentration, curves display always an active-passive behaviour.

The $I_{\text {corr }}$ value decreased with the addition of $25 \mathrm{ppm}$ of Actinidia deliciosa, butit increased with the addition of either 50 or $75 \mathrm{ppm}$, and then it decreases down to its lowest value when $100 \mathrm{ppm}$ were added. However, generally speaking, these values were higher tan those obtained with the addition of Extract 1, indicating a higher corrosion rates obtained with the addition of Extract 2. This is indicated by the inhibitor eefficiency values for Extract 2 in Table 2, showing that its highest inhibitor efficiency value was 90\% obtained with 100 ppm, whereas for Extract 1, the highest inhibitor efficiency was 95\% , at the same inhibitor concentration. The passive curent density value for extract 2 changed in the same fashion as the $I_{\text {corr }}$ value did: it decreased with the addition of $25 \mathrm{ppm}$ of inhibitor, but it increased with the addition of either 50 or $75 \mathrm{ppm}$, and it decreased once again when $100 \mathrm{ppm}$ of inhibitor were added. Both anodic and cathodic Tafel slopes were affected by the addition of Extract 2 of Actinidia deliciosa indicating that it is a mixed type of inhibitor. Figure 3 shows a plot

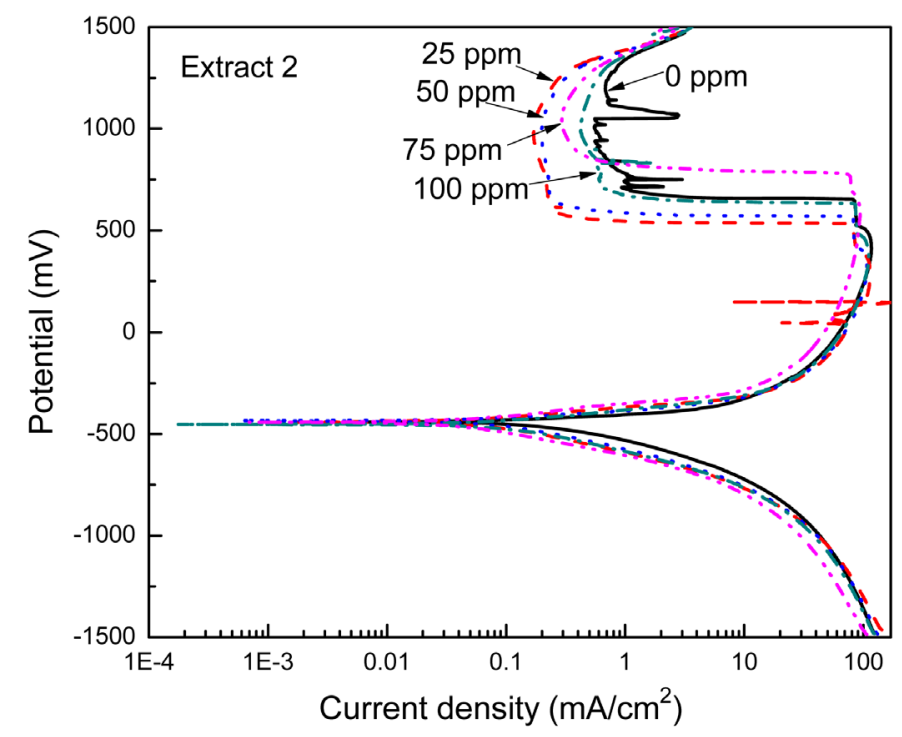

Figure 2. Effect of Extrcat 2 concentration of Actinidia deliciosa on the polazrization curves for 1018 carbon steel in $0.5 \mathrm{M} \mathrm{H}_{2} \mathrm{SO}_{4}$.

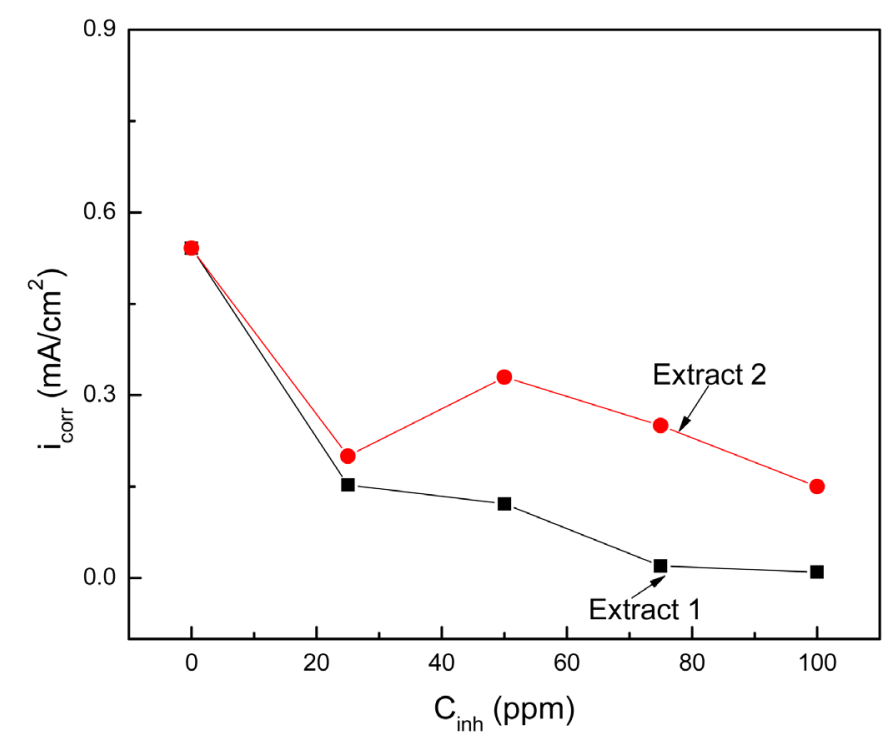

Figure 3. Effect of Extrcats 1 and 2 concentration of Actinidia deliciosa on the $I_{\text {corr }}$ values for 1018 carbon steel in $0.5 \mathrm{M} \mathrm{H}_{2} \mathrm{SO}_{4}$. 
Table 2. Electrochemical parameters obtained from polarization curves for 1018 carbon steel in $0.5 \mathrm{M} \mathrm{H}_{2} \mathrm{SO}_{4}$ with additions of Extract 2.

\begin{tabular}{cccccccc}
\hline$C_{\text {inh }}(\mathrm{ppm})$ & $I_{\text {corr }}\left(\mathrm{A} / \mathrm{cm}^{2}\right)$ & $E_{\text {corr }}(\mathrm{mV})$ & $\square(\%)$ & $\square \mathrm{a}(\mathrm{mV} / \mathrm{dc})$ & $\square \mathrm{c}(\mathrm{mV} / \mathrm{dc})$ & $E_{\text {pit }}(\mathrm{mV})$ & $I_{\text {pas }}\left(\mathrm{A} / \mathrm{cm}^{2}\right)$ \\
\hline 0 & 0.54 & -450 & --- & 58 & 145 & 1290 & 0.5 \\
25 & 0.20 & -442 & 63 & 42 & 150 & 1250 & 0.17 \\
50 & 0.33 & -436 & 38 & 38 & 168 & 1245 & 0.2 \\
75 & 0.25 & -456 & 53 & 66 & 145 & 1300 & 0.4 \\
100 & 0.15 & -448 & 90 & 54 & 125 & 1280 & 0.29 \\
\hline
\end{tabular}

of the change in the $I_{\text {corr }}$ with Actinidia deliciosa concentration for both extracts, where it can be seen that for both extracts, the corrosion current density value decreases with increasing their concentration.However, for Extract 2, the lowest $I_{\text {corr }}$ value was obtained by adding $25 \mathrm{ppm}$, increasing with a further increase in the inhibitor concentration up to $50 \mathrm{ppm}$, but after this concentration, the $I_{\text {corr }}$ value decreased once again. The corrosion current density values were higher for Extract 2 than those obtained with Extract 1 . The corrosion inhibition occurs due to the larger coverage of metal surface by the inhibitor molecules which increases with increasing its concentration. In order to be sure that the corrosion inhibition is due to the inhibitor adsorption on to the steel surface, several adsorption isotherms were calculated (Temkin, Frumkin and Langmuir isotherm), but, as shown in Figure 4, the best fitting was obtained with the Frumkin type of isotherm. Frumkin isotherm considers lateral interaction among the adsorbed molecules. The Frumkin isotherm is given by:

$$
\log \frac{\theta C}{1-\theta}=\log K+g \theta
$$

where $\theta$ is the metal surface covered by the inhibitor, given by the inhibitor efficiency divided by $100, C$ the inhibitor concentration and $K$ is the equilibrium constant of adsorption process. The $K$ value may be taken as a measure of the strength of the adsorption forces between the inhibitor molecules and the metal surface [18] Large values of $K$ imply more efficient adsorption and hence better inhibition efficiency [19]. By using Figure 3, the $K$ value can be calculated, which is 19.9, and the Gibbs standard free energy of adsorption for the inhibitor $\Delta \mathrm{G}^{0}$ was estimated by using the equation [20] [21]:

$$
\Delta \mathrm{G}^{0}=-R T \ln (k)
$$

Generally, values of $\Delta \mathrm{G}^{0}$ up to $-20 \mathrm{~kJ} \cdot \mathrm{mol}^{-1}$ are consistent with electrostatic interaction between charged molecules and a charged metal (which indicates physical adsorption) while those more negative than -40 $\mathrm{kJ} \cdot \mathrm{mol}^{-1}$ involves charge sharing or transfer from the inhibitor components to the metal surface to form a coordinate type of bond (which indicates chemisorption) [22] [23]. In the present study, the value of $\Delta \mathrm{G}^{0}$ is 1.95 $\mathrm{kJ} \cdot \mathrm{mol}^{-1}$ indicates that the adsorption of Actinidia deliciosaon carbon steel surface involves physical adsorption.

The effect of Extract 1 of Actinidia deliciosa concentration in the Nyquist plots for 1018 carbon steel in $0.5 \mathrm{M}$ $\mathrm{H}_{2} \mathrm{SO}_{4}$ is shown in Figure 5, where it can be seen that data describe a single, deppressed, capacitive-like semicircle at all frequency values, with their centers at the real axis and their diameters increasing with the concentration, which indicates that the Surface covered by Actinidia deliciosa increases with increasing its cocnentration. The presence of a single semicircle indicates that the corrosion process is under charge tranfer control form the metal to the electrlyte and it does not change with the addition of Actinidia deliciosa. For extract 2, in Figure 6, Nyquist diagram display capacitive-like, deppressed semicircles at all concentrations, except at $25 \mathrm{ppm}$, where a small inductive loop can be observed at the lowest frequency values. This inductive loop indicates that the corrosión process is under the adorption/desorption of some species such as the complex formed by the $\mathrm{Fe}^{2+}$ ions and the inhibitor [23] [24]. The highest semicircle diameter, and thus the lowest corrosión rate, is obtained with $25 \mathrm{ppm}$ of Actinidia deliciosa, just like the results shown in Figure 3, and it decreases with increasing the inhibitor concentration. The change in the charge transfer resistance, $R_{c t}$, or the semicircle diameter, for both extracts is given in Figure 7, where it can be seen that for Extract 1, this value increases with increasing the inhibitor concentration, unlike Extrcat 2, where the highest vallue is obtained with the addition of $25 \mathrm{ppm}$ of inhibitor, and then it decreases with s further increase in the inhibitor concentration.

Somemicrographs of corroded samples without and with $100 \mathrm{ppm}$ of Extract 1 for Actinidia deliciosa is shown in Figure 8. For specimens corroded in the uninhibited solution, Figure 8(a), surface shows a very porous, 


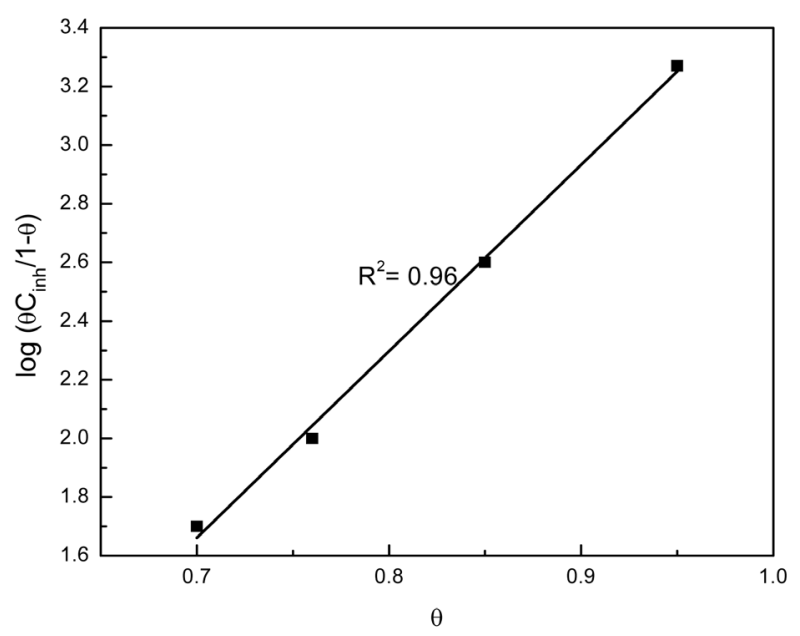

Figure 4. Frumkin adsorption isotherm for 1018 carbon steel in $0.5 \mathrm{M} \mathrm{H}_{2} \mathrm{SO}_{4}$ with additions of Extract 1 of Actinidia deliciosa.

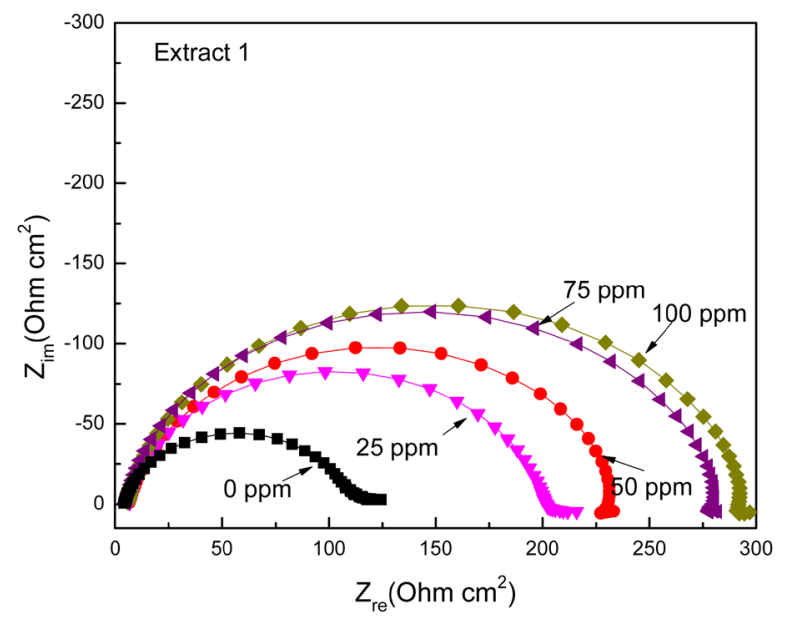

Figure 5. Effect of Extrcat 1 concentration of Actinidia deliciosa on the Nyquist diagramas for 1018 carbon steel in $0.5 \mathrm{M} \mathrm{H}_{2} \mathrm{SO}_{4}$.

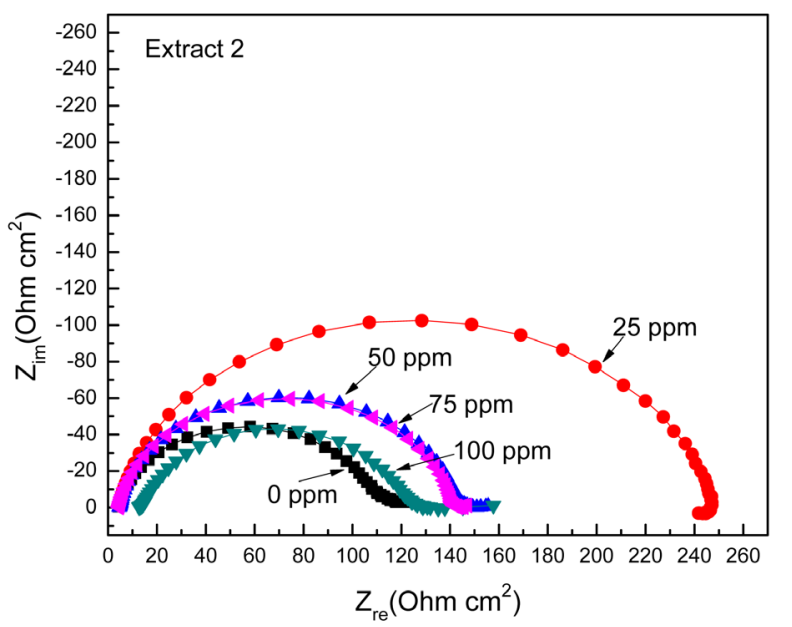

Figure 6. Effect of Extrcat 2 concentration of Actinidia deliciosa on the Nyquist diagramas for 1018 carbon steel in $0.5 \mathrm{M} \mathrm{H}_{2} \mathrm{SO}_{4}$. 


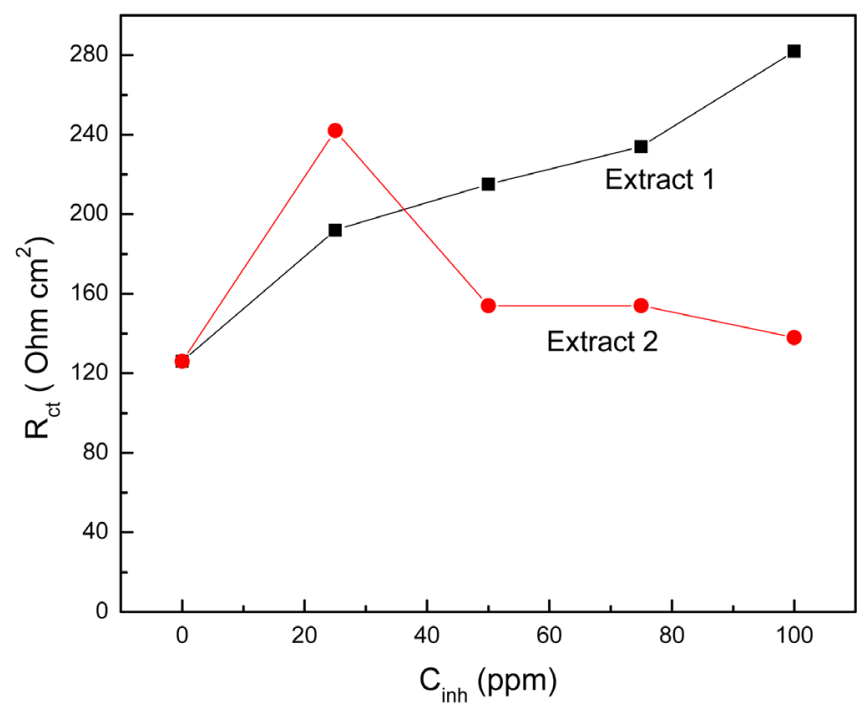

Figure 7. Effect of Extrcats 1 and 2 concentration of Actinidia deliciosa on the $R_{\mathrm{ct}}$ values for 1018 carbon steel in $0.5 \mathrm{M} \mathrm{H}_{2} \mathrm{SO}_{4}$.
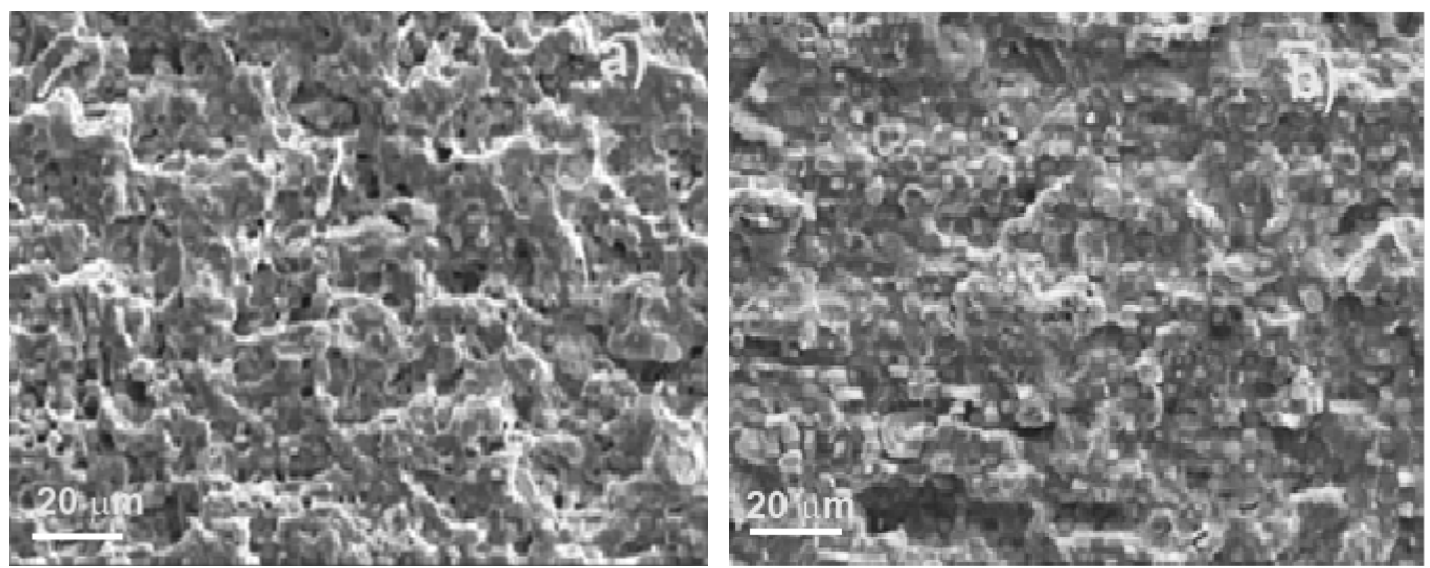

Figure 8. SEM micrographs of 1018 carbon steel corroded in $0.5 \mathrm{M} \mathrm{H}_{2} \mathrm{SO}_{4}$ containing (a) 0 and (b) $100 \mathrm{ppm}$ of extract 1 of Actinidia deliciosa.

non-protective film, whereas for specimen tested in the inhibited solution, Figure 8(b), surface showed a more compact, protective film, without porous.

In order to know which compound present in the Actinidia deliciosa and might be the responsable for its inhibitory ability, some FTIR tests were performed, and the spectrum for the pure extract is shown in Figure 9 where it can be seen a peak present at $3474 \mathrm{~cm}^{-1}$ which probably correspond to phenols [25] [26], maily by the quercitine, which has a chemical structure as shown in Figure 10, due to the presence of the $\mathrm{OH}^{-}$group at 3417 $\mathrm{cm}^{-1}$, and a peak at $1384 \mathrm{~cm}^{-1}$ which suggests the presence of the methil group. A peak present at $2028 \mathrm{~cm}^{-1}$, corresponds to a combination of substitued aromatic groups, which is confirmed by the peak at $622 \mathrm{~cm}^{-1}$. The peak present at $1628 \mathrm{~cm}^{-1}$ suggests the presence of either the carbonil, $\mathrm{C}=\mathrm{O}$, group, or a $\mathrm{C}-\mathrm{O}-\mathrm{C}$ link, or $\mathrm{C}=\mathrm{C}$ links. It is believed that the formation of a complex formed with $\mathrm{Fe}^{2+}$ ions and $\mathrm{OH}^{-}$groups present are the responsible to give the corrosion protection to the metal.

Once Extract 1 has been added to the acid, before carrying out the corrosión test, in Figure 11, once again the $\mathrm{OH}^{-}$group can be seen at $3474 \mathrm{~cm}^{-1}$, whereas the combination of the peaks at $2028 \mathrm{~cm}^{-1}$ and $619 \mathrm{~cm}^{-1}$, correspond to a combination of substitued aromatic groups. The peak present at $1628 \mathrm{~cm}^{-1}$ suggests the presence of either the carbonil, $\mathrm{C}=\mathrm{O}$, group, or a $\mathrm{C}-\mathrm{O}-\mathrm{C}$ link, or $\mathrm{C}=\mathrm{C}$ links and a methil group at $1384 \mathrm{~cm}^{-1}$. Finally, for extract 1 added to the acid and after the corrosión test, Figure 12, the same pekas observed before the corrosion 


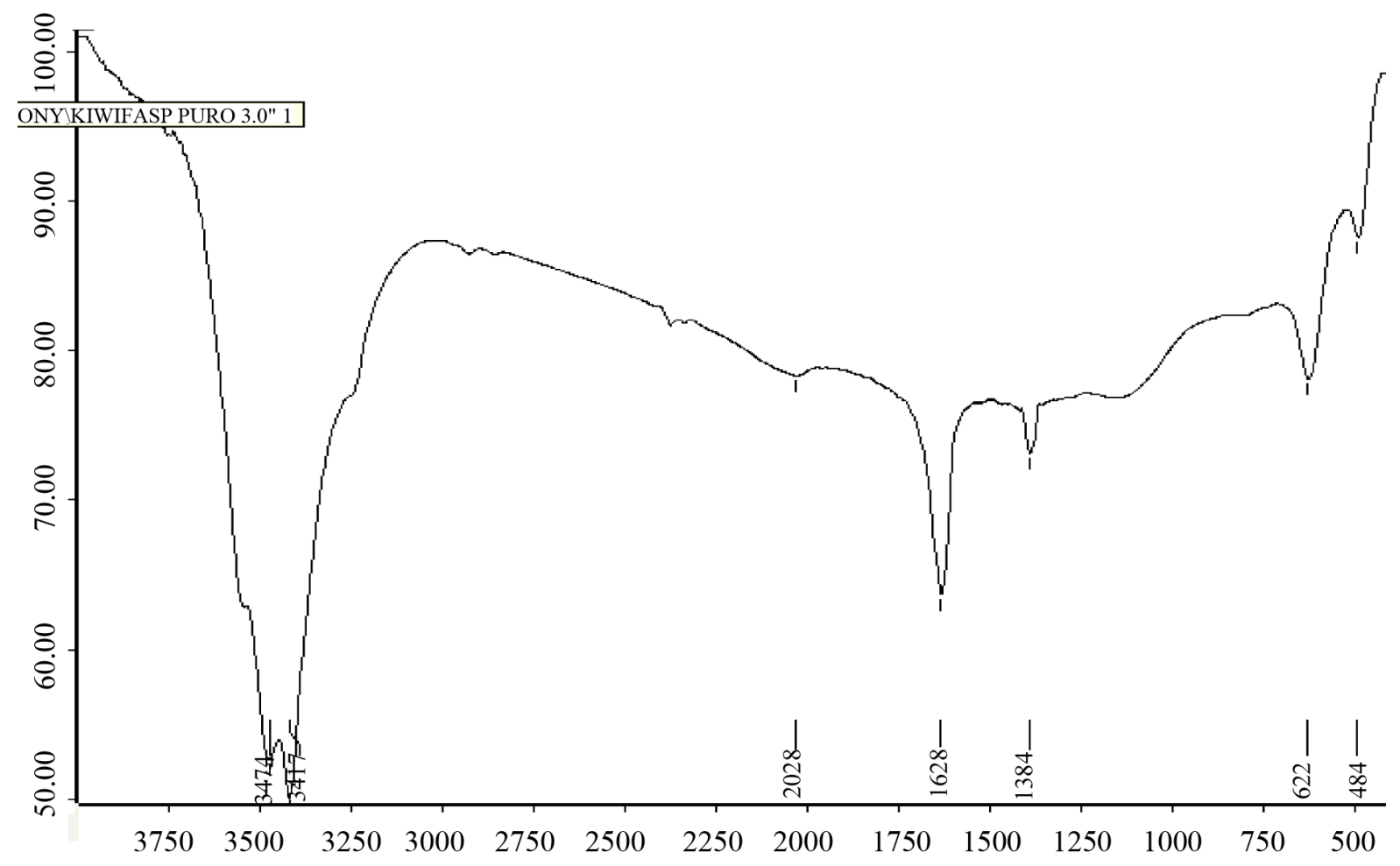

Figure 9. FTIR spectrum for pure Extract 1 of Actinidia deliciosa.<smiles>O=c1c(O)c(-c2ccc(O)c(O)c2)oc2cc(O)cc(O)c12</smiles>

Figure 10. Chemcial structure of quercitine.

tests are observed, but their intensity decreases, maybe due to their interaction with $\mathrm{Fe}^{2+}$ ions to form a complex, a corrosion product film, which is the responsible for the corrosion inhibition. It is believed that the high inhibitive performance of this extract suggests a strong bonding of the Actinidia deliciosa derivatives, such as quercitine, on the metal surface due to presence of lone pairs from heteroatom (oxygen) and p-orbitals, blocking the active sites and therefore decreasing the corrosion rate. Therefore, bonding between inhibitor molecules onto carbon steel surface occurs through sharing electrons of the $\mathrm{OH}$ group present in the compounds of the pure extract and vacant d-orbitals of iron.

\section{Conclusion}

A study of the use of tender and ripe Actinidia deliciosa extracts as corrosion inhibitor for 1018 carbon steel in $0.5 \mathrm{M} \mathrm{H}_{2} \mathrm{SO}_{4}$ has been carried out. Results indicate that both kind of extracts acted as good corrosión inhibitors, is more efficient in the ripe extract. Corrosion inhibition efficiency increases with increasing its concentration for mature extract, whereas for the tender Actinidia deliciosa, the higest inhibitor efficiency is obtained by adding 25 ppm, decresing with a further increase in its concentration. Both extracts improve the passive film 


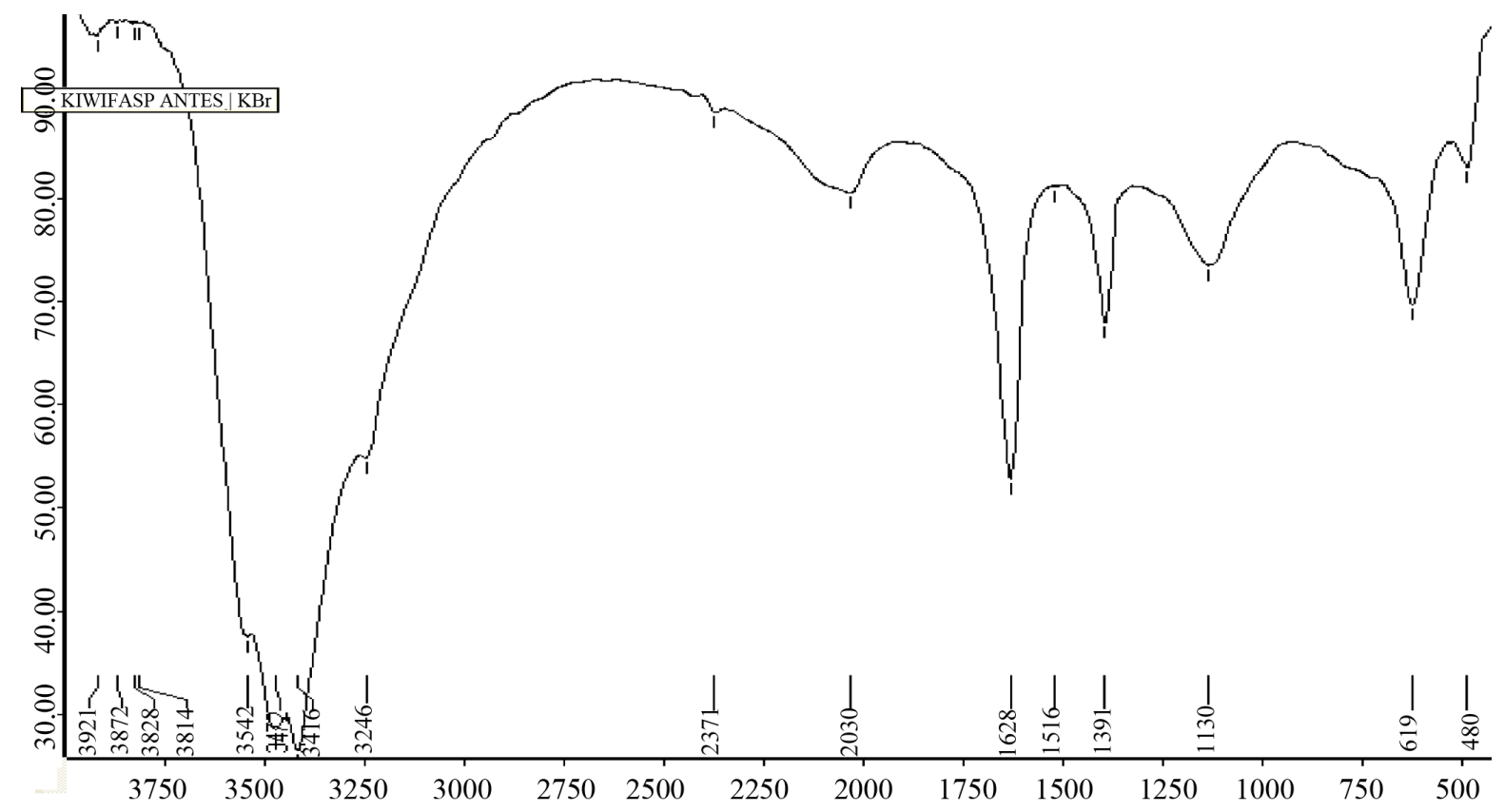

Figure 11. FTIR spectrum for $\mathrm{H}_{2} \mathrm{SO}_{4}+100 \mathrm{ppm}$ of Extract 1 of Actinidia deliciosa before the corrosion test.

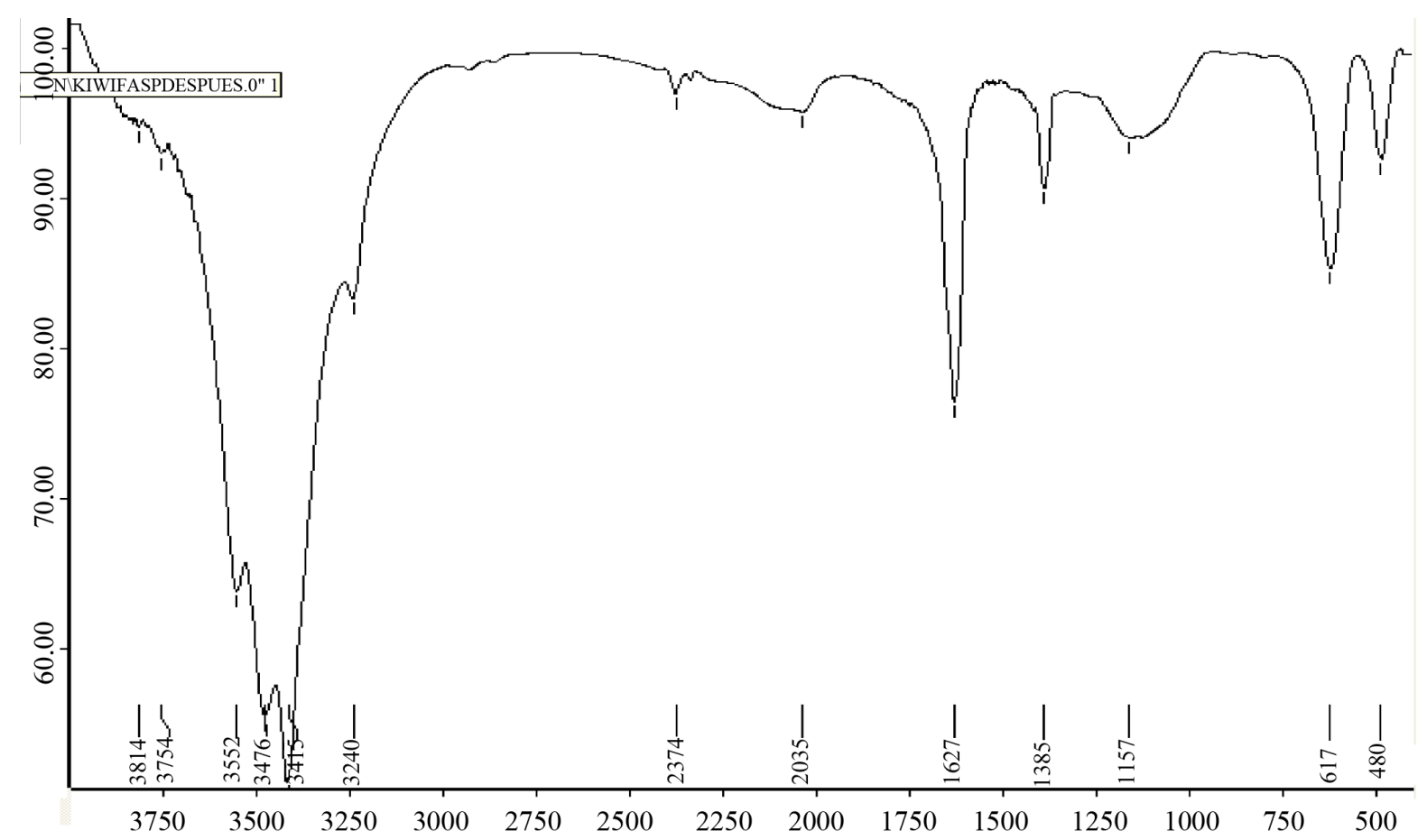

Figure 12. FTIR spectrum for $\mathrm{H}_{2} \mathrm{SO}_{4}+100 \mathrm{ppm}$ of Extract 1 of Actinidia deliciosa after the corrosion test.

properties by decreasing the passive current density values. It is found that the corrosion inhibition is due to the presence of heteroatoms present in Actinidia deliciosa, mainly quercitine, which is physically adsorbed in the steel following a Frumkin type of adsorption isotherm and forms a protective film.

\section{References}

[1] El-Etre, A.Y. (2006) Khillah Extract as Inhibitor for Acid Corrosion of SX 316 Steel. Applied Surface Science, 252, 
8521-8525. http://dx.doi.org/10.1016/j.apsusc.2005.11.066

[2] Gece, G. (2011) Drugs: A Review of Promising Novel Corrosion Inhibitors. Corrosion Science, 53, 3873-3898. http://dx.doi.org/10.1016/j.corsci.2011.08.006

[3] Prabhu, D. and Rao, P. (2013) Coriandrum sativum L.-A Novel Green Inhibitor for the Corrosion Inhibition of Aluminium in 1.0 M Phosphoric Acid Solution. Journal of Environmental Chemical Engineering, 1, 676-683. http://dx.doi.org/10.1016/j.jece.2013.07.004

[4] Asipita, S.A., Ismail, M., Majid, M.Z.A., Majid, Z.A., Abdullah, C.S. and Mirza, J. (2014) Green Bambusa Arundinacea Leaves Extract as a Sustainable Corrosion Inhibitor in Steel Reinforced Concrete. Journal of Cleaner Production, 67, 139-146. http://dx.doi.org/10.1016/j.jclepro.2013.12.033

[5] Garai, S., Garai, S., Jaisankar, P., Singh, J.K. and Elango, A. (2012) A Comprehensive Study on Crude Methanolic Extract of Artemisia pallens (Asteraceae) and Its Active Component as Effective Corrosion Inhibitors of Mild Steel in Acid Solution. Corrosion Science, 60, 193-204. http://dx.doi.org/10.1016/j.corsci.2012.03.036

[6] Raja, P.B., Qureshi, A.K., Rahim, A.A., Osman, H. and Awang, K. (2013) Neolamarckia Cadamba Alkaloids as EcoFriendly Corrosion Inhibitors for Mild Steel in $1 \mathrm{M} \mathrm{HCl} \mathrm{Media.} \mathrm{Corrosion} \mathrm{Science,} \mathrm{69,} \mathrm{292-301.}$ http://dx.doi.org/10.1016/j.corsci.2012.11.042

[7] Patel, N.S., Hrdlicka, J., Beranek, P., Přibyl, M., Šnita, D., Hammouti, B., Al-Deyab, S.S. and Salghi, R. (2014) Extract of Phyllanthus fraternus Leaves as Corrosion Inhibitor for Mild Steel in $\mathrm{H}_{2} \mathrm{SO}_{4}$ Solutions. International Journal of Electrochemical Science, 9, 2805-2815.

[8] Khadraoui, A., Khelifa, A., Boutoumi, H., Hamitouche, H., Mehdaoui, R., Hammouti, B. and Al-Deyab, S.S. (2014) Adsorption and Inhibitive Properties of Ruta chalepensis L. Oil as a Green Inhibitor of Steel in 1 M Hydrochloric Acid Medium. International Journal of Electrochemical Science, 9, 3334-3348.

[9] Fares, M.M., Maayta, A.K. and Al-Qudah, M.M. (2012) Pectin as Promising Green Corrosion Inhibitor of Aluminum in Hydrochloric Acid Solution. Corrosion Science, 60, 112-117. http://dx.doi.org/10.1016/j.corsci.2012.04.002

[10] Mourya, P., Banerjee, S. and Singh, M.M. (2014) Corrosion Inhibition of Mild Steel in Acidic Solution by Tagetes erecta (Marigold Flower) Extract as a Green Inhibitor. Corrosion Science, 85, 352-363. http://dx.doi.org/10.1016/j.corsci.2014.04.036

[11] Du, G., Li, M., Ma, F. and Liang, D. (2009) Antioxidant Capacity and the Relationship with Polyphenol and Vitamin C in Actinidia Fruits. Food Chemistry, 113, 557-562. http://dx.doi.org/10.1016/j.foodchem.2008.08.025

[12] Motohashi, N., Shirataki, Y., Kawase, M., Tani, S., Sakagami, H. and Satoh, K. (2001) Biological Activity of Kiwifruit Peel Extracts. Phytotherapy Research, 15, 337-343. http://dx.doi.org/10.1002/ptr.876

[13] Rush, E., Ferguson, L.R., Cumin, M., Thakur, V., Karunasinghe, N. and Plank, L. (2006) Kiwifruit Consumption Reduces DNA Fragility: A Randomized Controlled Pilot Study in Volunteers. Nutrition Research, 26, 197-201. http://dx.doi.org/10.1016/j.nutres.2006.05.002

[14] D’Evoli, L., Moscatello, S., Lucarini, M., Aguzzi, A., Gabrielli, P., Proietti, S., Battistelli, A., Famianic, F., Böhm, V. and Lombardi-Boccia, G. (2015) Nutritional Traits and Antioxidant Capacity of Kiwifruit (Actinidia deliciosa Planch., cv. Hayward) Grown in Italy. Journal of Food Composition and Analysis, 37, 25-29. http://dx.doi.org/10.1016/j.jfca.2014.06.012

[15] Silva, A.B., Agostinho, S.M.L., Barcia, O.E., Cordeiro, G.G.O. and D’Elia, E. (2006) The Effect of Cysteine on the Corrosion of 304L Stainless Steel in Sulphuric Acid. Corrosion Science, 48, 3668-3674. http://dx.doi.org/10.1016/j.corsci.2006.02.003

[16] Ismail, K.M. (2007) Evaluation of Cysteine as Environmentally Friendly Corrosion Inhibitor for Copper in Neutral and Acidic Chloride Solutions. Electrochimica Acta, 52, 7811-7819. http://dx.doi.org/10.1016/j.electacta.2007.02.053

[17] Obot, I.B. and Obi-Egbedi, N.O. (2010) An Interesting and Efficient Green Corrosion Inhibitor for Aluminium from Extracts of Chlomolaena odorata L. in Acidic Solution. Journal of Applied Electrochemistry, 40, 1977-1984. http://dx.doi.org/10.1007/s10800-010-0175-X

[18] Bora, K.S. (2011) The Genus Artemisia: A Comprehensive Review. Pharmaceutical Biology, 49, 211-220. http://dx.doi.org/10.3109/13880209.2010.504732

[19] Gomathi, R., Priyadharshini, T., Kirithika, T. and Usha, K. (2013) Comparative Lipid Peroxidation, Leaf Membrane Thermostability, and Antioxidant System in Four Sugarcane Genotypes Differing in Salt Tolerance. International Journal of Pharmaceutical Research and Bio-Science, 2, 29-38.

[20] Rana, M.G., Katbamna, R.V., Padhya, A.A., Dudhrejiya, A.D., Jivani, N.P. and Sheth, N.R. (2010) In Vitro Antioxidant and Free Radical Scavenging Studies of Alcoholic Extract of Medicago sativa L. Romanian Journal of Biology_Plant Biology, 55, 15-22.

[21] Velázquez-González, M., Gonzalez-Rodriguez, J.G. and Valladares-Cisneros, M.G. (2014) Use of Rosmarinus offici- 
nalis as Green Corrosion Inhibitor for Carbon Steel in Acid Medium. American Journal of Analytical Chemistry, 5, 5564. http://dx.doi.org/10.4236/ajac.2014.52009

[22] Kertit, S., Chaouket, F., Srhiri, A. and Keddam, M. (1994) Corrosion Inhibition of Amorphous FeBSiC Alloy in 1 M HCI by 3-Amino-1,2,4-triazole. Journal of Applied Electrochemistry, 24, 1139-1145. http://dx.doi.org/10.1007/BF00241312

[23] Li, X., Deng, S. and Fu, H. (2012) Inhibitive Effects and Mechanism of Phosphates on the Stress Corrosion Cracking of Brass in Ammonia Solutions. Corrosion Science, 62, 163-175. http://dx.doi.org/10.1016/j.corsci.2012.05.008

[24] Lagrenée, M., Mernari, B., Bouanis, M., Traisnel, M. and Bentiss, F. (2002) Study of the Mechanism and Inhibiting Efficiency of 3,5-Bis(4-methylthiophenyl)-4H-1,2,4-triazole on Mild Steel Corrosion in Acidic Media. Corrosion Science, 44, 573-588. http://dx.doi.org/10.1016/S0010-938X(01)00075-0

[25] Houghton, P.J., Mensah, A.Y., Iessa, N. and Yong-Hong, L. (2003) The Scientific Basis for the Reputed Activity of Valerian. Photochemistry, 64, 385-393. http://dx.doi.org/10.1016/S0031-9422(03)00264-4

[26] Avila, A., Guilhermo, J. and Romo de Vivar, A. (2003) Triterpenoid Saponins and Other Glycosides from Buddleja scordioides. Biochemical Systematics and Ecology, 30, 1003-1005. http://dx.doi.org/10.1016/S0305-1978(02)00032-7 